\title{
Impact of Privatization on Airport Performance: Analysis of Polish and British airports
}

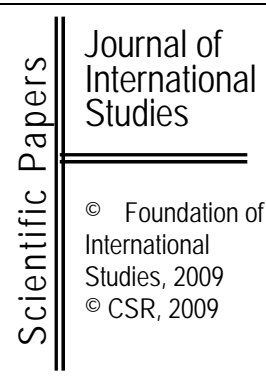

Wojciech Augustyniak

Poznań University of Economics

augustyniak@gmail.com

\begin{abstract}
This paper surveys the changes in ownership patterns and profitability at British and Polish airports. The analysis is intended to compare the financial effectiveness of the main British airports before and after their privatization and to use the British experience as a benchmark when considering the effectiveness and aims of selling Polish airports. The analysis covers year 1986 and 2005 in UK and period 2000-2007 in Poland. The efficiency is measured in terms of the earnings generated by each passenger using EBITDA (Earnings before Interest, Taxes, Depreciation, and Amortization). The main aim of the paper is to present different ways of privatisation and to verify the efficiency of the British model. Results of the analysis are intended for establishing some policy considerations and to analyze some possible implications which could arise from a future privatization of the Polish airport system.
\end{abstract}

Keywords: British and Polish airports, airport privatization, deregulation, EBITDA.

JEL classification: L33, P1, P51

\section{Introduction}

Airports have always been an essential part of national and military aviation systems. After the Second World War, airfields were commonly taken over by government for military use. Therefore, landing fields and their infrastructure were always considered as a public utility, rather than as competitive companies. In this situation, operational activities for many years played a crucial role, whereas financial results were contemplated as being less important. In the late 80 's the situation started to change due to the emerging processes of corporatization, commercialization and eventually privatization.

Currently, airfields are no longer just considered as suppliers of transport infrastructure. Governments are progressively regarding aviation industry companies as potential profitmaking enterprises. Liberalization measures are common in this sector, accompanied by a process of partial or total privatization of services and infrastructure. Within the sector, airports, air traffic control facilities and government airlines are increasingly given a more commercial orientation, and in many cases they have been partially or fully privatized. 


\section{Advantages and Threats}

Many economists claim that private airport ownership would provide a better set of incentives for viable long-term efficiency in the industry.

The main aims of privatization are:

- improvements in competition and operating efficiency (the private owners are more eager to cut costs and to boost revenues)

- introduction of new commercially focused management styles and marketing skills directed at more consumer-oriented management with better investment decisions

- reduction of government financial involvement and public investment in the industry

- provision of access to private investment

- changing the role of the government from owner and operator to regulator

Regardless of all its potential benefits, privatization also involves risks. Therefore it requires careful regulation and control from public authorities. The main threat of selling airport shares is the possibility of transforming the airport into a private local monopoly which may:

- increase aeronautical fees to exorbitant levels

- cut costs too much and lead to inadequate investment

- deliver poor standards of service

- give insufficient consideration to non operational issues such as environmental impacts and maintaining social justice

\section{Types of privatization}

Airport privatization can occur in different ways. Privatization models broadly fall into five categories:

1. Share flotation. The company's share capital is totally or partially floated on the stock market. Management might be given options to acquire shares which may imply stronger identification with the company. The stock company will have to get used to the daily scrutiny of its financial performance by its shareholders and other investors.

2. Trade sell. Some parts of the airport or the entire airport are sold to a trade partner usually through a public tender. Usually governments prefer to involve strategic partners rather than just a passive investor. This means that the management and technological expertise of the partners as well as their financial capabilities are taken into account.

3. Concession. An airport management company purchases a concession or lease to operate the airport for a defined period of time (usually between 20 and 30 years). The concessionaire takes full economic risk and is responsible for all operations and investments. Government has a greater degree of control than with trade sell and receives a regular income.

4. Project finance privatization. The investor usually builds or converts and then operates specific airport facilities (e.g. terminal) for a certain period. This type of arrangement does not require a large upfront payment but the private company has to bear all the costs of building the facility.

5. Management contract. The ownership remains with the government, which stays responsible for the investments, but the contractor takes responsibility for the operation of the airport, typically for a period of 5 to 10 years. The government either pays an annual management fee to the contractor, usually related to the airport performance, or the contractor pays the government a share of its revenues. 


\section{Privatization process in United Kingdom}

The preferred model of privatization in Europe has been the sale of equity. The British government was the forerunner of this process. The trend towards privatization began in the UK in the late 80 's and it was intended to reduce the amount of public money spent on lossmaking public sector industries. In 1987 the British government privatized its seven major airports by share flotation, selling the British Airport Authority (BAA), including Heathrow, Gatwick, Stansted, Southampton, Glasgow, Edinburgh and Luton airports. The public sector deficit disappeared in 1987 but privatization (mostly by trade sell) was still pursued as a politically and economically attractive means to finance tax cuts and develop airport infrastructure.

Table 1 shows absolute values of throughput at main British airports in 1986 and 2005. The gray background marks the airports which had less than 1 million passengers in 2005 . Table 2 shows the changes in ownership and in profitability at 20 main British airports. The efficiency is measured in terms of the earnings generated by each passenger using EBITDA (Earnings before Interest, Taxes, Depreciation, and Amortization). In order to make the data comparable over a period when tax law and accountancy practices might have changed the EBITDA/passenger ratio does not include depreciation, interest and tax.

Table 1 Passenger traffic at main UK airports 2000-2005

\begin{tabular}{|c|c|c|c|}
\hline Passengers $* 1000$ & 1986 & 2005 & change \\
\hline Aberdeen & 1452 & 2954 & $49 \%$ \\
\hline Belfast & 1882 & 4823 & $39 \%$ \\
\hline Birmingham & 1725 & 9386 & $18 \%$ \\
\hline Bournemouth & 137 & 916 & $15 \%$ \\
\hline Bristol & 436 & 5157 & $8 \%$ \\
\hline Cardiff & 436 & 1772 & $25 \%$ \\
\hline Durham Tees Valley & 297 & 899 & $33 \%$ \\
\hline East Midlands & 941 & 4155 & $23 \%$ \\
\hline Edinburgh & 1756 & 8507 & $21 \%$ \\
\hline Exeter & 105 & 874 & $12 \%$ \\
\hline Glasgow & 3200 & 8830 & $36 \%$ \\
\hline Leeds Bradford & 508 & 2601 & $20 \%$ \\
\hline Liverpool & 263 & 4654 & $6 \%$ \\
\hline London Gatwick & 16751 & 32851 & $51 \%$ \\
\hline London Heathrow & 32092 & 67437 & $48 \%$ \\
\hline London Luton & 1635 & 9150 & $18 \%$ \\
\hline London Stansted & 577 & 22337 & $3 \%$ \\
\hline Manchester & 7596 & 27593 & $28 \%$ \\
\hline Newcastle & 1165 & 5234 & $22 \%$ \\
\hline Norwich & 191 & 584 & $33 \%$ \\
\hline average: & 3657 & 11036 & $33 \%$ \\
\hline av. $100 \%$ private: & 4257 & 12305 & $189 \%$ \\
\hline av. $100 \%$ state-owned: & 1857 & 7227 & $289 \%$ \\
\hline av. Partial & 844 & 4025 & $377 \%$ \\
\hline average $>1 \mathrm{mln}$ pas. & 4526 & 13590 & $200 \%$ \\
\hline average $<1 \mathrm{mln}$ pas. & 183 & 818 & $348 \%$ \\
\hline
\end{tabular}

Source: own compilation based on: 'Graham A., (2008), Managing Airports: An International Perspective, Elsevier, 
Table 2. Profitability growth and ownership patterns at main UK airports 2005.

Consolidated data: $2005=100 \%$

\begin{tabular}{|l|rrr|rr|}
\hline EBITDA/Pas. [GBP] & \multicolumn{1}{|c|}{$\mathbf{1 9 8 6}$} & 2005 & change & $\begin{array}{c}\text { Private } \\
\text { interest }\end{array}$ & $\begin{array}{c}\text { year of } \\
\text { privatization }\end{array}$ \\
\hline Aberdeen & 1,84 & 4,43 & $140 \%$ & $100 \%$ & 1987 \\
Belfast Int. & 3,73 & 2,21 & $-41 \%$ & $100 \%$ & 1994 \\
Birmingham & 7,02 & 5,54 & $-21 \%$ & $51 \%$ & 1997 \\
Bournemouth & 2,14 & 3,82 & $79 \%$ & $0 \%$ & -- \\
Bristol & 4,63 & 5,62 & $21 \%$ & $100 \%$ & 1997 \\
Cardiff & 2,82 & 4,07 & $44 \%$ & $100 \%$ & 1995 \\
Durham T.V. & 0,81 & $-1,58$ & $-294 \%$ & $75 \%$ & 2003 \\
East Midlands & 6,90 & 5,54 & $-20 \%$ & $0 \%$ & -- \\
Edinburgh & 2,85 & 4,55 & $60 \%$ & $100 \%$ & 1987 \\
Exeter & $-1,00$ & 11,61 & $1258 \%$ & $0 \%$ & -- \\
Glasgow & 3,07 & 4,00 & $30 \%$ & $100 \%$ & 1987 \\
Leeds Bradford & 7,50 & 1,86 & $-75 \%$ & $0 \%$ & -- \\
Liverpool & $-13,94$ & 3,95 & $128 \%$ & $100 \%$ & 1990 \\
London Gatwick & 5,67 & 4,00 & $-29 \%$ & $100 \%$ & 1987 \\
London Heathrow & 6,62 & 8,65 & $31 \%$ & $100 \%$ & 1987 \\
London Luton & 4,37 & 2,38 & $-46 \%$ & $100 \%$ & 1987 \\
London Stansted & $-5,57$ & 3,35 & $160 \%$ & $100 \%$ & 1987 \\
Manchester & 4,40 & 4,73 & $7 \%$ & $0 \%$ & -- \\
Newcastle & 4,99 & 5,43 & $9 \%$ & $49 \%$ & 2001 \\
Norwich & $-0,52$ & 3,17 & $705 \%$ & $80 \%$ & 2003 \\
\hline average: & 2,42 & 4,37 & $81 \%$ & & \\
\hline 100\% private: & 1,46 & 4,29 & $110 \%$ & & \\
100\% state: & 3,99 & 5,51 & $38 \%$ & & \\
partial ownership & 3,07 & 3,14 & $2 \%$ & & \\
\hline average $>1$ mln pas. & 2,93 & 4,39 & $50 \%$ & & \\
average $<1 m l n$ pas. & 0,36 & 4,26 & $1097 \%$ & & \\
\hline
\end{tabular}

Source: own compilation based on:

Graham A., (2008), Managing Airports: An International Perspective, Elsevier, Office for National Statistics website http://www.statistics.gov.uk/

The impact of privatization on airport performance is hard to measure due to a range of factors that have contributed to the changes. For example, a passenger throughput of over 1 million per year causes a scale effect which induces a remarkable boost in financial results. Nevertheless, the biggest growth in profitability between 1986 and 2005 was noted in small regional airports $(+1097 \%$ in consolidated values). The EBITDA per passenger ratio grew slower during this period at big international airports $(+50 \%)$. Despite the slower rate of growth the absolute values are clear. Each passenger in 2005 contributed on average to a higher EBITDA growth at international airports $(£ 4,39)$ than at regional ones $(£ 4,26)$.

In 1986, four out of 20 main airports were unprofitable. In 2005 only partially stateowned Durham Tees Valley airport suffered a financial loss. During 19 years 14 out of 20 airports improved efficiency and only 6 decreased the financial results. Generally, statecontrolled companies achieved better results ( $£ 5.51$ per passenger) than private ones ( $£ 4.29$ per passenger). However, the rate of growth was higher in companies managed by entirely private enterprises $(+110 \%)$ than in those controlled completely by the state $(+38 \%)$. 
It is important to note that the worst value of efficiency dynamics were observed in airports owned and managed partially by the state and partially by private investors. A $2 \%$ growth rate over a period of 19 years might be an outcome of disharmony between the priorities of private management and public affairs.

\section{Current situation in Poland}

Polish law does not allow private investors to buy more than $49 \%$ of shares of international airports. It also prohibits the building of new ones. What is more, every shares sale over $24,9 \%$ to a non-state-owned enterprise must be approved by the president of Civil Aviation Office. The Polish Government plans to introduce new laws which may cause privatization to be even more difficult. Until 2009 only Bydgoszcz Ignacy Jan Paderewski Airport was owned partially by private capital.

In 2008, the authorities sold 48,98\% of shares to a private company - Meinl Airports International Ltd. The others are owned by state-owned companies, cities or voivodeships. Tables 2 and 3 present passenger traffic and profitability of 8 main Polish airports, excluding Warsaw Frederic Chopin Airport due to data confidentiality.

Table 3 Passenger traffic at main Polish airports 2000-2005

\begin{tabular}{|l|rrrrrrrr|}
\hline & \multicolumn{1}{|c}{2007} & \multicolumn{1}{c}{2006} & \multicolumn{1}{c}{2005} & \multicolumn{1}{c}{2004} & \multicolumn{1}{c}{2003} & \multicolumn{1}{c}{2002} & \multicolumn{1}{c|}{2001} & \multicolumn{1}{c|}{2000} \\
\hline KRK & 3068199 & 2367257 & 1586130 & 841123 & 593214 & 500852 & 549298 & 517015 \\
KTW & 1995914 & 1458411 & 1092358 & 622612 & 257991 & 202267 & 180015 & 168126 \\
GDN & 1708739 & 1249780 & 677946 & 463840 & 365036 & 318033 & 319174 & 269960 \\
WRO & 1270825 & 857931 & 454047 & 355431 & 284334 & 236151 & 237705 & 210873 \\
POZ & 863018 & 637021 & 399255 & 351036 & 263551 & 227498 & 227914 & 227874 \\
LCJ & 312365 & 204718 & 18063 & 6226 & 7320 & 1936 & 2652 & 794 \\
SZZ & 228071 & 176670 & 101801 & 90811 & 87435 & 76816 & 69890 & -- \\
BZG & 181576 & 133009 & 38682 & 25354 & 20064 & 13408 & 6821 & 14089 \\
\hline
\end{tabular}

Source: own compilation based on airports' annual reports and websites.

Table 4 Profitability growth at main Polish airports 2000-2005.

Consolidated data: $2005=100 \%$

\begin{tabular}{|c|c|c|c|c|c|c|c|c|}
\hline $\begin{array}{c}\text { EBITDA/Pas. } \\
\text { [GBP] }\end{array}$ & 2007 & 2006 & 2005 & 2004 & 2003 & 2002 & 2001 & 2000 \\
\hline KRK & 5,62 & 6,91 & 4,98 & 5,12 & 5,51 & 5,32 & 6,84 & 7,21 \\
\hline KTW & 3,80 & 2,78 & 3,58 & 5,36 & 5,47 & 4,07 & 3,64 & 3,77 \\
\hline GDN & 2,58 & 2,37 & 2,24 & 2,81 & 4,01 & 3,85 & 3,06 & 3,65 \\
\hline WRO & 2,19 & 2,03 & 1,48 & 3,27 & 2,85 & 1,56 & 2,91 & 3,30 \\
\hline POZ & 2,76 & 3,40 & 3,82 & 5,42 & 5,86 & 2,38 & 1,04 & 2,94 \\
\hline LCJ & $-3,34$ & $-7,38$ & $-75,07$ & $-137,15$ & -- & -- & -- & -- \\
\hline SZZ & $-2,20$ & $-2,81$ & $-3,56$ & $-1,62$ & $-7,28$ & $-14,78$ & $-16,65$ & -- \\
\hline BZG & $-4,05$ & $-9,94$ & $-12,39$ & -- & -- & $-43,10$ & $-39,87$ & $-19,51$ \\
\hline average: & 0,92 & $-0,33$ & $-9,37$ & $-16,68$ & 2,74 & $-5,81$ & $-5,57$ & 0,23 \\
\hline av $>1 \mathrm{mln}$ pas. & 3,55 & 3,52 & 3,07 & 4,14 & 4,46 & 3,70 & 4,11 & 4,48 \\
\hline av $<1 \mathrm{mln}$ pas. & $-1,71$ & $-4,18$ & $-21,80$ & $-44,45$ & $-0,71$ & $-18,50$ & $-18,49$ & $-8,28$ \\
\hline
\end{tabular}

Source: own compilation based on „Dziennik Urzędowy Rzeczpospolitej Polskiej Monitor Polski B" 
Airports are divided into two groups according to the number of passengers. The first group consists of "mature" airports which had more than 1 million passengers in 2007. Those companies are characterized by very small dynamics of EBITDA per passenger ratios over the period. In fact, 3 out of 4 airports decreased their financial efficiency. What is more, the growth from $£ 3.77$ to $£ 3.80$ of Katowice International Airport (KTW) was hardly noticeable. Most of the smaller airports make a loss, but there is noticeable trend of improvement. The only "immature" "young" profitable airport was Poznań-Ławica (POZ). However, its passenger throughput in 2007 was close to 1 milion (863k), which is almost 3 times more than at Lodz-Airport - second in the group.

The comparison of financial data of Polish and British airports shows that efficiency in Poland is still lower ( $£ 4,39$ to $£ 3,55$ at bigger airports and $£ 4,26$ to $£-1,71$ at smaller ones). However, it seems highly probable that the difference is mainly caused by the scale effect associated with huge traffic grow. Average passenger traffic at any one of 20 main UK airports exceeds 10 million passengers a year, whereas in Poland only Krakow-Balice-Airport had more than 2 million passengers in 2007. Nevertheless, it seems that there are good perspectives for the development of the smaller companies. The $1097 \%$ boost in efficiency of small British airports seems to be a good example to follow.

\section{Conclusion}

European governments are faced with assessing whether private ownership is the solution to capacity constraints and the rising need for investment. Corporatization and privatization are thought to improve the performance of airports, but in order for these measures to be effective they need to be accompanied with adequate processes for economic regulation. A remarkable observation is that some airports operate in the area of increasing returns to scale and some in the area of decreasing returns to scale. That is why airports with throughput of over 1 million passengers are analyzed separately to those with throughput of under 1 million.

The data suggests that privatized British airports improved their profitability during the period 1986 to 2005 . However, it is hard to asses how far this was due to traffic grow and how far this was due to changes in ownership and management style. Nevertheless, the highest rates of efficiency growth were observed at small and entirely privately-owned airports, which might mean that they are more sensitive to changes in ownership. Results of the analysis clearly show that the financial performance of small Polish airports are poor. Therefore, it may be assumed that the complete trade sell of small airports in Poland may result in very high growth in financial performance in subsequent years.

However, the same hypothesis cannot be made in relation to bigger companies due to small differences in performance and vast dissimilarity of passenger traffic. However, it is highly probable that after privatization, growth in the airports' performance should also be observed due to access to private funds and a profit orientated management style. In conclusion, the British example might offer the suggestion that due to various reasons (e.g. improvements in competition and more flexible management) airport privatization in Poland may result in improvements in its financial effectiveness. Additionally, it might be also a good way to repair deficits in the national budget without harming the economy. 


\section{References}

1. Al-Jazzaf M,. (1999), Impact of privatization on airlines performance: an empirical analysis, Journal of Air Transport Management

2. Frost \& Sullivan (2006), Airport Privatisation, Frost \& Sullivan

3. Graham A., (2008), Managing Airports: An International Perspective, Elsevier,

4. Humphreys I., (1999), Privatization and commercialization changes in UK airport ownership patterns, Journal of Air Transport Management

5. Kaliński D., Krzemiński S., (2000), Rola kapitału prywatnego w finansowaniu infrastruktury Transportowej, Uniwersytet Szczeciński

6. Martin J.C., (2001), An application of DEA to measure the efficiency of Spanish airports prior to privatization, Journal of Air Transport Management

7. Ruciński A, (2006), Porty Lotnicze wobec polityki otwartego nieba, Fundacja Rozwoju Uniwersytetu Gdańskiego

8. Starke D., (2008), Aviation Markets: Studies in Competition and Regulatory Reform, Ashgate

9. Vasigh B., Fleming K., Tacker T., (2008), Introduction to Air Transport Economics From Theory to Applications, Ashgate

10. Wells A.T., Young S.B. (2004), Airport Planning \& Management, McGraw-Hill 